\title{
BENEDEK ZOLTÁN
}

\section{Digitális adatok a helyszínen}

\begin{abstract}
A bünügyi helyszínen mára nemcsak a klasszikus értelemben vett nyomok és anyagmaradványok találhatók meg, hanem a különböző elektronikai eszközök által tárolt, külső szemlélő elől rejtett adatok is, amelyeknek kiemelkedő bizonyító erejük lehet. A szakértői tevékenység bővülése következtében a szemlebizottság már „nem sétál el” az elektronikai eszközök mellett, hanem egyre nagyobb számban foglalják le öket, tartalmukat pedig igazságügyi informatikus szakértő vizsgálja meg. Nem is jelenthető ki, hogy csak egy bizonyos büncselekménytípusnál javasolt lefoglalni ilyen eszközöket, gondoljunk csak arra, hogy akár egy mobiltelefon is rejthet olyan felvételt, amely múltban lejátszódó releváns történéseket rögzített videófelvétel vagy fénykép formájában. Legyen szó informatikai rendszer útján elkövetett csalásról, vagy kábítószer-kereskedelemröl, számtalan olyan helyzet adódhat a gyakorlatban, ami a számítógépek, adathordozók, telekommunikációs eszközök lefoglalását teszi szükségessé.

A helyszínen nemcsak az elektronikai eszközök által tárolt digitális adatok felkutatásának, rögzítésének van kiemelkedő szerepe, hanem a bünüldöző hatóságok által alkalmazott olyan eszközöknek is, amelyek a digitális technika segítségével rögzítik a helyszíni állapotokat.

A digitális adat megszámlálhatatlan formában létezik. A technika rohamos fejlődése nyomán szinte évente jelennek meg újabb és újabb eszközök, amelyeket a nyomozó hatóságok a bizonyítás szolgálatába tudnak állítani. Különbséget lehet tenni azon eszközök között, amelyekkel a helyszínen találkozunk, illetve alkalmazunk, valamint azok között, amelyeket a szakértők alkalmaznak a begyüjtött nyomok és anyagmaradványok vizsgálata során. A parttalanság elkerülése érdekében az eszközök közül a dolgozatomban csak néhányat tudok bemutatni, azonban megemlíthető a digitális hangazonosítás, a képanyagelemzés, az íriszazonosítás, a rekonstrukciós szoftverek, a biometrikus szkennelés vagy a rádiófrekvenciás helyazonosítás, amelyek a legújabb technikai fejlődés vívmányai. ${ }^{1}$
\end{abstract}

1 Fenyvesi Csaba: A kriminalisztika tendenciái. Dialóg Campus Kiadó, Budapest-Pécs, 2014, 68. o. 
Ezek mindegyike kiemelt szerepet kap manapság a bünüldözés eszköztárában. A digitális hangazonosítás lényege, hogy a rossz minőségü felvételeket ma már képesek vagyunk feljavítani, így megállapíthatjuk az elkövető hangját, leszürhetjük a zavaró háttérzajt, így akár képesek vagyunk meghatározni a helyszínt. ${ }^{2}$ A képanyagelemzés során a szakértők képesek az adott személy mozgását folyamatosan figyelni, megállapítani, hogy tart-e magánál fegyvert vagy egyéb tárgyat. ${ }^{3}$ A biometrikus szkennelés mind a bünmegelözésben, mind a felderítésben kiemelt szerepet kap, ahogy a rádiófrekvenciás helyazonosítás is, hiszen mind az elkövetö, mind a sértett mozgása modellezhető és ellenőrizhetö. ${ }^{4}$

\section{Digitális adatok felkutatása}

A büncselekmény helyszínén a nyomok és anyagmaradványok mellett lefoglalás tárgya lehet maga a számítógép is, a hozzá tartozó adathordozókkal együtt, pontos rögzítésük és későbbi vizsgálatuk bizonyítékként felhasználható. Ha a számítógéphez nyomtató is csatlakozik, indokolt lehet a nyomtató, és az általa kinyomtatott dokumentumok lefoglalása is, hiszen bizonyos büncselekményfajtáknál relevánsak lehetnek. ${ }^{5}$

A számítógépes környezetben elkövetett büncselekmények relatíve gyorsan és anonimitást kínálva segítik az elkövetőket. A helyszíniszemle-bizottság többnyire a kézzelfogható nyomok és anyagmaradványok felkutatására koncentrál, de az elektronikus bizonyítékok felkutatásáról sem lehet megfeledkezni. Ha sikerrel végzünk ilyen irányú kutatást, akkor is nagy körültekintéssel kell eljárni, mivel egy elektronikus bizonyíték olyan sérülékeny, mint egy ujjnyom.

Elektronikus bizonyítékokra lelhetünk például internetes levelezésben, böngészési előzményekben, felhasználónevekben, fényképekben, videókban, híváslistákban vagy akár GPS-elözményekben és koordinátákban is.

Hogyha számítógépet foglalunk le, akkor beszélhetünk látható bizonyítékokról (például CD-k), azonban nagyobb számban vannak jelen láthatatlan elemek is. Ilyenek például a gépben lévő memóriakártyák, telefonok esetében a híváselőzmények, PDA-készülékekben, tabletekben lévő adatok, okostele-

\footnotetext{
2 Uo. 68-69. o.

3 Uo. 69-70. o.

4 Uo. 71 . o.

5 Ken Lidstone -Vaughan Bevan - Clare Palmer: Bevan and Lidstone's The Investigation of Crime. A Guide to Police Powers. Second Editon, Butterworths, 1996, p. 143.
} 
fonokban lévő képek, videók, szervereken tárolt adatok, nyomtatókban tárolt információk, merevlemezek és szkennerek.

A rögzítésük során gondosan dokumentálni kell az elhelyezkedésüket, típusukat, darabszámukat, azonosítási számaikat, majd nem statikus zacskóba kell csomagolni öket. Ha nyomkutatás válik szükségessé például egy CD-n vagy merevlemezen, akkor kerülni kell a mágnespor használatát az elektronikus bizonyítékok károsodásának megelőzése érdekében. ${ }^{6}$

A számítógépes környezetben elkövetett büncselekmények tipikus formája a különböző vírusok küldése, másolóprogramok használata, adathalászat, hamis adatok szolgáltatása, blokkolóprogramok küldése, logikai bombák használata a számítógép megbénítása érdekében, és számtalan más módszer. Ezek feltárása, bizonyítása és az elkövetö kilétének a felderítése szakértő segítségével lehetséges, ami az esetek nagy részében meglehetősen nehéz, egyes esetekben pedig lehetetlen. ${ }^{7}$

A digitális bizonyítékoknak napjainkban egyre nagyobb jelentőségük van, ezért a helyszíni szemlénél a bizottságnak nagyobb figyelmet kell rájuk fordítania. A számítógépes környezetben elkövetett büncselekmények lehetősége egyre szélesebb, gondoljunk akár a csalásra, a kábítószer-kereskedelemre, vagy a prostitúció esetére. A számítógépes világ folyamatosan változik és fejlődik, ezért a bizonyítás során a nyomozó hatóságoknak is készen kell állniuk arra, hogy sikerrel vegyék fel a harcot ezek ellen.

A digitális bizonyítékok láthatatlanok, mint az ujjnyom vagy a DNS, könynyen elrejthetők, megsemmisíthetők és meg is semmisülhetnek. A digitális bizonyítékok felkutatása esetén gondot kell fordítani az összegyüjtésre, a biztosításra és a szállításra.

Fontos az azonosításuk, méretük és feltalálási helyük dokumentálása, majd a csomagolásuk és a szállításuk. Ennek során figyelemmel kell lenni a megfelelő helyszínbiztosításra, az adatok megváltoztatatlanságára. Ennek során, amennyiben a számítógép bekapcsolt állapotban van, nem szabad megnyitni a különböző fájlokat, nem szabad kikapcsolni szakértő segítsége nélkül. Fontos, hogy ha a képernyő is bekapcsolt állapotban van, le kell fényképezni a képet, ha pedig egy törlőprogram futását észleljük, azonnal áramtalanításra van szükség.

Számítógépek esetében beszélhetünk különféle adattároló eszközökről, amelyek lefoglalása nagymértékben hozzájárulhat a keresett adatállomány

\footnotetext{
6 Ngaire Genge: The Forensic Casebook. The Science of Crime Scene Investigation. Ballantine Books, New York, 2002, p. 201.

7 Michael D. Lyman: Criminal Investigation. 8th Editon. Pearson, Columbia College of Missouri, 2016, p. 487.
} 
megtalálásához. Ilyenek lehetnek például a külső és belső merevlemezek, USB-porton keresztül használható adattároló eszközök és memóriakártyák. Az adattároló eszközök lefoglalásán kívül fontos megemlíteni a billentyüzetet, az egeret, valamint a gépházat is, amelyeken szintén jó eséllyel találhatók ujjlenyomatok, vagy emberi eredetü biológiaianyag-maradványok. ${ }^{8}$

A különböző tárgyak csomagolása esetén pontosan kell dokumentálni a folyamatot, számozást kell alkalmazni, illetve fényképfelvételeket kell készíteni. Ennek során nem szabad elfelejteni, hogy az eszközök esetleg különböző anyagmaradványokat hordozhatnak, ezért nagy odafigyeléssel kell eljárni a minták megsemmisülésének vagy szennyeződésének elkerülése érdekében. A csomagolóanyagnak egy nem statikus papírzacskónak kell lennie, de az egyes tárgyak eredeti tárolódobozát is használható. Biztosítani kell, hogy a tárgyak ne sérüljenek, ne rongálódjanak meg a müvelet folyamán, illetve a szállításkor. Ha mobiltelefon lefoglalására kerül sor, azt kikapcsolt állapotban, az akkumulátorát és a benne található SIM- és memóriakártyákat kiszedve kell csomagolni.

Szállítás során a digitális adatokat tartalmazó eszközöket óvni kell a fizikai behatásoktól, valamint az elektromos és mágneses mezőktől. Itt fontos megjegyezni, hogy a tárgyra kedvezőtlenül hat a rendőrautóban lévő szolgálati rádió által gerjesztett elektromágneses mezö.

Mobiltelefonok, GPS- és PDA-készülékek lefoglalása esetén jó eséllyel lehet hívásadatokhoz, helyszínekhez és különböző útvonalakhoz információt gyüjteni. Itt megemlíthető a bejövő- és kimenőhívás-lista, hívó és hívott adatok, cellainformációk és elmentett útvonaltervek. ${ }^{9}$

\section{Szakértő bevonása}

A szakértő bevonásának szükségessége nem szerepel a jogszabályban, mindig az adott eset határozza meg, szükség van-e szakértő bevonására. Ez alapesetben akkor szükséges, ha a bizonyítandó tény megállapításához különleges szakértelem kell, illetve kötelező szakértőt kirendelni, ha a személyazonosítást biológiai vizsgálattal végzik. ${ }^{10} \mathrm{~A}$ digitális adatokról különösen elmondható, hogy már a legelső intézkedések megtételekor javasolt szakértö jelenléte, köz-

\footnotetext{
8 Kevin Lothridge: Crime Scene Investigation: A Guide for Law Enforcement. National Forensic Science Technology Center, 2013, p. 113.

9 Aric W. Dutelle: An Introduction to Crime Scene Investigation. Second Editon. Jones \& Bartlett Learning, 2014, p. 401.

10 A büntetőeljárásról szóló 1998. évi XIX. törvény 99. §.
} 
remüködése. A szakértő jelenlétében, javaslatainak figyelembevételével sokkal eredményesebben kutathatjuk fel, illetve rögzíthetjük az adatokat. A szakértő adott esetben már a helyszínen is meg tudja állapítani, hogy az adott eszköz lefoglalása szükséges-e, ezzel megelőzve a felesleges dolgok elvonását a tulajdonos birtokából. Álláspontom szerint a szakértő aktív közremüködése átveszi az adott szakasz irányítását, iránymutatásával, javaslataival nagyban hozzájárulhat a helyszín minél alaposabb átvizsgálásához. Például egy informatikus szakértő - ha rendelkezésére állnak a megfelelö eszközök - már a helyszínen is átvizsgálhatja a memóriakártyák, merevlemezek, mobiltelefonok tartalmát, ezzel meggyorsítva, megkönnyítve az eljárás e szakaszát.

Ha a szakértő az eljárási cselekménynél nincs jelen, vagy egyéb módon - telekommunikációs eszközön keresztül - nem segíti a munkát, akkor a bizonyítás során határozni kell a szakértő kirendeléséről. A szakértő a részére megküldött kirendelő határozatban foglalt kérdések figyelembevételével vizsgálja át az informatikai eszközöket, adathordozókat, e müvelethez speciális keresőprogramok segítik.

A legföbb szakértői rendszerek közül megemlíthető a Belkasoft ${ }^{11}$, a Mobiledit ${ }^{12}$, az Autopsy és The Sleuth $\mathrm{Kit}^{13}$, az Andriller ${ }^{14}$, a Caine ${ }^{15}$ és az $\mathrm{UFED}^{16}$. Ezek a szakértői rendszerek gyakorlatilag ízekre szedik az eszközöket, legyen az számítógép vagy okostelefon, legyen az Windows- vagy Linux-, iOS- vagy Android-alapú. Teljes körü listát képesek összeállítani az eszközökben szereplő adatokról (rejtett fájlokról is), azok keletkezési idejéről, sőt a GPS-koordináták és hívásadatok, cellaadatok segítségével még az eszköz korábbi tartózkodási helyei is megállapíthatók. A programok még a törölt állományokról is tudnak információkkal szolgálni, ezek adott esetben visszaállíthatók. Az igazságügyi szakértő a felsorolt automatikusan müködő programok segítségével térképezi fel a digitális adatokat, majd a feltett kérdések megválaszolásával alakítja ki véleményét. Ha az adatállomány birtoklása jogszabályba ütközik (például gyermekpornográfia esetében), a szakértő törölheti, vagy ideiglenesen hozzáférhetetlenné teheti öket. ${ }^{17}$

\footnotetext{
$11 \mathrm{https}: / /$ belkasoft.com/ec

$12 \mathrm{http}: / /$ www.mobiledit.com/products/

$13 \mathrm{http} / / / \mathrm{www}$.sleuthkit.org/index.php

$14 \mathrm{http}: / / \mathrm{www}$. andriller.com/

$15 \mathrm{http}: / / \mathrm{www} . c a i n e-$ live.net/

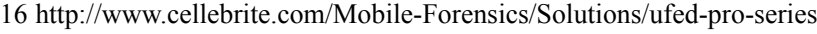

17 A büntetőeljárásról szóló 1998. évi XIX. törvény 158/B §.
} 


\section{Digitális eszközök alkalmazása a szemlén}

A bünügyi helyszínen a hatóság is alkalmazhatja a rendelkezésére álló legújabb kriminalisztikai eszközöket. A számtalan eszköz közül azokat mutatom be, amelyek a magyar gyakorlatban megtalálhatók. Megítélésem szerint a Nemzeti Szakértöi és Kutatóközpont a legfrissebb eljárások kidolgozásának, eszközök tesztelésének centruma. A központon kívüli helyi szervek elvétve alkalmazzák a bemutatott eszközöket, ennek föként a szükös pénzügyi keret és a megfelelően kiképzett szakemberhiány az oka.

\section{A drón alkalmazása}

A drón mint szó, leginkább pilóta nélküli repülőgépet jelent. Napjainkban igen nagy szerephez jut, hiszen nemcsak a civil szektorban, hanem a bünüldözésben és a rendvédelemben is kiemelt szerepet kap. Elsősorban katonai, illetve hírszerzési feladatok ellátására alkották meg őket, később azonban más területeken is elkezdték alkalmazni. ${ }^{18}$ A magyar rendvédelmi szervek is használnak drónokat, alkalmazásukat a jövőben több területre kívánják kiterjeszteni, például rendezvénybiztosításkor, tömegkezelési feladatoknál, a közlekedési helyzet megfigyelésére, terepkutatásnál, elfogásoknál, rajtaütéseknél és szemléknél. ${ }^{19} \mathrm{~A}$ drón alkalmas megfigyelésre olyan területeken, ahol más technikai eszköz alkalmazása nem lenne megoldható, emellett nemcsak nappal, de éjszaka is használható. ${ }^{20}$ Kiválóan alkalmazható katasztrófavédelmi feladatok ellátására is, tüzfelderítésre vagy épp kárfelmérésre. ${ }^{21}$ Hatótávolság alapján több csoportba sorolhatók, így beszélhetünk csak látótávolságig vezérelhető eszközökröl, rádió-távirányítással müködő, wifi támogatott és GPS-eszközökröl. ${ }^{22}$

Jelenleg nincs olyan magyar jogszabály, amely meghatározná a drónok alkalmazását, hiszen ezeknek jelenleg nem lajstromjelük sincs. ${ }^{23} \mathrm{~A}$ légi közle-

\footnotetext{
18 Nagy Attila: Pilóta nélküli légi járművek - a technológia bemutatása, aktualitásai, jogi háttere. Szakmai Szemle, 2015/2., 116. o.

19 Petrétei Dávid: A drónok krimináltechnikai és rendészeti felhasználása. Magyar Bünüldöző, 2015/1-3., 3. o.

20 Petrétei Dávid: Kriminalisztikai fényképészet - helyszínek fényképes dokumentálása. In: Szabó Gyula (szerk.): Munkabaleseti helyszínek dokumentálása. Óbudai Egyetem, Budapest, 2014, 11-12. o.

21 Vránics Dávid - Üveges András: Pilóta nélküli légi jármüvek fejlődése. Felderítő Szemle, 2015/2., 130. o.

22 Uo. 128. o.

23 Petrétei Dávid (2014): i. m. 4. o.
} 
kedésről szóló 1995. évi XCVII. törvény hatálya alá tartoznak, és használatukra a Nemzeti Közlekedési Hatóság Légügyi Hivatalától kell engedélyt kérni. ${ }^{24}$ Természetesen történik próbálkozás a jogi háttér megteremtésére, hiszen ez mind a civil szektor, mind a rendvédelem szempontjából elengedhetetlen, így példa lehet hazánk számára az Egyesült Államokban vagy épp Németországban alkalmazott szabályozás. ${ }^{25} \mathrm{~A}$ drónok alkalmazása természetesen több veszélyt is rejt magában, hiszen szándékos jogellenes cselekmények elkövetésére is felhasználható, így minden esetben szükség van a kockázatok felismerésére, és ezek szabályozására, akár úgy, hogy engedélyhez kötjük az alkalmazásukat. ${ }^{26}$

A drónok jövőbeni szélesebb körủ alkalmazása megjelenhet egyebek között a gyanúsítottak megfigyelésében, felkutatásában (akár infrakamera segítségével), védett személyek és területek biztosításában, wifihálózat ellenőrzésében vagy zavarásában, valamint a határvédelem terén. Drónokat nemcsak a hatóságok vethetnek be, hanem akár az elkövetők is. Gondolhatunk akár az embercsempészés büncselekményére, ahol az elkövetők is megfigyelhetik a járörök mozgását a határterületen. A drón esetleges lefoglalása is segítséget nyújthat a bizonyítás során, hiszen GPS-adatokat tárolhat, e koordináták térképre illesztése megmutatja az eszköz korábbi mozgásának helyszínét.

\section{$3 D$ térszkenner}

A 3D térszkenner napjainkban a térbeli adatszerzés legjobb módszere, hiszen gyorsan, több millió pont koordinátáiból megállapítható egy objektum geometriai adata. ${ }^{27} \mathrm{~A}$ körbeforgó lézer gömbhéjszerüen letapogatja a környezetet, akár olyan sürüséggel, hogy ötven méter távolságban minden négyzetmilliméterre jut egy sugár. A szoftver a kész gömbpanoráma-felvételt ráilleszti a fénypontfelhőre. A különböző álláspontokból felvett fénypontfelhőket és gömbpanoráma-képeket a szoftver hibátlanul összeilleszti. Abból a célból, hogy használható legyen a kész anyag, elegendő álláspontból kell a felvételeket elkészíteni, nehogy valamely terület kimaradjon. A térszkenner magassága fix, a lézersugár pedig egyenes. A helyszínen kell meghatározni, hogy

\footnotetext{
24 Nagy Attila: i. m. 117. o.

25 Petrétei Dávid (2014): i. m. 6-8. o.

26 Beck Attila: Az UAV-k polgári alkalmazásának kockázatai, és kezelésük lehetséges módszerei terrorelhárítási és személyvédelmi szempontból. (T)error\&elhárítás, 2015/2., 3. o. http://epa.oszk.hu/02900/02932/00008/pdf/EPA02932_terror_elharitas_2015_2_01.pdf

27 Pásztor László: A 3D térszkenner müködése, tapasztalatok, lehetséges további felhasználási területek. Belügyi Szemle, 2016/7-8., 65. o.
} 
hol legyenek az egyes álláspontok, illetve egyáltalán hány álláspontból szükséges felvételt készíteni. A kész kép térben elforgatható, így szinte beleélhetjük magunkat a helyszínbe. ${ }^{28}$

A 3D térszkenner megfelelően használható müemlékvédelem, ipari alkalmazás, eszközgyártás, katasztrófavédelem, igazságügy, valamint a bünügyi nyomozás során. ${ }^{29}$ Maga az eszköz alkalmas metszetek készítésére, rekonstrukcióra. ${ }^{30}$ Eltérő változatai vannak, így beszélhetünk állványos 3D lézerszkennerről, fogászati szkennerről vagy kézi szkennerről. Míg a térszkenner fontossága az összképrögzítésnél ragadható meg, addig a kézi szkenner a nyomrögzítésnél kap meghatározó szerepet. ${ }^{31}$ A 2015. július 11-én, Tatabányán, lőfegyverrel elkövetett emberölés helyszínén a térszkenner segítségével megállapíthatóvá vált az elkövető helyzete a lövés pillanatában, illetve az, hogy célzottan történt-e az elkövetés. ${ }^{32}$

\section{Talajradar}

A talajradart 2014 óta alkalmazzák a bünügyi helyszíni szemléknél. ${ }^{33}$ A talajradar képes felismerni a talaj összetételétől eltérő objektumokat, és ezáltal megmondani azok pontos helyét és mélységét. A talajradarral történő vizsgálat kétféle módon történik, az egyik módja a helyszíni mérő és jelölő módozat, míg a másik a rácshálós módszerrel történő feltérképezés és vizsgálat. ${ }^{34}$ A talajradar bünügyekben való alkalmazását jelentős eredmények támasztják alá, így indokolt a jövőbeni alkalmazás. Gyakorlati példát említve a talajradart akár elrejtett, elásott holttestek felkutatására is használni lehet.

\section{Képalkotás}

A képalkotás jelentőségét véleményem szerint nem kell hangsúlyozni, hiszen a krimináltechnika egyik fő szakterülete. A képkészítés az idők folyamán jelentős fejlődésen ment keresztül, amíg eljutott a ma ismert és alkalmazott eljárásokig. Míg az 1950-es években sztereofényképek készültek, napjainkban

\footnotetext{
28 Petrétei Dávid (2014): i. m. 107. o. 29 Pásztor László: i. m. 66. o.

30 Uo.

31 Petrétei Dávid: Háromdimenziós képalkotás a kriminalisztikában. Belügyi Szemle, 2016/7-8., 84. o. 32 Pásztor László: i. m. 67. o.

33 Mama Sándor - Gárdonyi Gergely: A talajradar használatának gyakorlati tapasztatai a hazai bünügyi helyszínelésben. Belügyi Szemle, 2016/7-8., 70-71. o. $34 \mathrm{Uo}$
} 
a digitális képek uralják a világot, ezek közé sorolható a helyszínelésnél alkalmazott gömbpanorámakép. ${ }^{35}$

A modern gömbpanorámakép-rögzítők (például PanoScan, SpheronVR) méretarányos digitális képeket hoznak létre, amelyeken utólagos mérések is végezhetők. Továbbá a számítógép segítségével elkészített gömbpanoráma gyakorlatilag szabadon mozgatható-forgatható, így háromdimenziós modell lesz. A megörökített virtuális helyszín fényképminőségü részleteihez a programban hozzárendelhetünk helyszíni fényképeket, jegyzőkönyvrészleteket, vagy videófelvételeket. A legfejlettebb háromdimenziós képalkotó rendszer jelenleg a háromdimenziós lézeres térszkenner. ${ }^{36}$

\section{Pásztázó elektronmikroszkópia}

Az első elektronmikroszkópot 1935-ben alkották meg, azóta számos példány készült belöle, jelentőségét pedig annak köszönheti, hogy egyrészt a minta elökészítése egyszerü, másrészt a legjobb adatokat ismerhetjük meg általa. ${ }^{37}$ A pásztázó elektronmikroszkópnak alapvetően két fö része van, az egyik a torony, a másik a vezérlő egység, a tápegység, a kép létrehozásához pedig fókuszált elektronsugarat alkalmaznak. ${ }^{38}$ A pásztázó elektronmikroszkóp leginkább felületek letapogatására, valamint preparátumok megvizsgálására, anyagösszetétel megállapítására alkalmas. Lényegét és müködését tekintve elmondható, hogy „az e-nyaláb - minta kölcsönhatásból származó jeleket detektáljuk, majd erösités után képalkotásra használjuk". Az elektronmikroszkóppal a képalkotásra több lehetőség is van, alkalmazhatjuk a visszaszórt elektronmódszert, a szekunder elektronmódszert vagy a próbaáramos rendszert. Fontos megjegyeznünk, hogy jelentöségét nemcsak annak köszönheti, hogy kis mintáról ad számunkra információt, hanem a felület összetételének megállapítására is alkalmas. ${ }^{39}$ Gyakorlati alkalmazása az anyagmaradványok vizsgálatára terjed ki, különösen a csappantyú-anyagmaradványok felkutatására. ${ }^{40}$

\footnotetext{
35 Petrétei Dávid (2016): i. m. 77-79. o. 


\section{Röntgen}

A post mortem radiológia segítségével a testről olyan átvilágító, feltérképező felvételeket készíthetünk, amelyek támpontot adhatnak az elkövetés körülményeiről. A röntgensugárzás nagy energiájú elektromágneses sugárzás, amelynek hullámhossza a néhányszor 10 nanométer és a néhányszor 10 pikométer közé esik. Legfontosabb felhasználási területei az orvostudomány és a kristálytan. A röntgensugárzásban terjedő röntgenfoton energiája élettanilag veszélyes. A röntgensugarak biológiai hatása - gondos adagolás és ellenőrzés esetén - sok betegség gyógyításánál előnyösen alkalmazható (röntgenterápia rosszindulatú daganatos megbetegedéseknél). Az eljárás kifejlesztése Wilhelm Conrad Röntgen német tudós nevéhez köthetö (1895). Napjainkban a radiológiát a személyazonosításban, a kormeghatározásban és a halál okainak vizsgálatára is használják. Emellett az igazságügyi radiológia megtalálható a csomagok és jármüvek átvizsgálásánál, kábítószerek kutatásánál és müvészeti tárgyakkal kapcsolatos csalásoknál.

Alkalmazása a gyakorlatban megtalálható csontok törésének megállapításában, a lövedékek károkozásának és egyéb sérülések vizsgálatában, valamint az ujjlenyomat és a DNS mellett mint kisegítő lehetőség, segítségül szolgálhat a személyazonosításban. Erre példa egy törött csontról készült röntgenfelvétel összehasonlítása az orvosi nyilvántartásokban szereplőkkel. ${ }^{41}$

\section{$C T$}

A komputertomográfia (CT) a radiológiai diagnosztika egyik ága. A tomográfia szó szeletre utal. A tomográfiás felvételeken a vizsgálat tárgya képzeletbeli szeletekre bontva látható. Az eszköz kifejlesztéséért 1979-ben Allan M. Cormack és Godfrey N. Hounsfield orvosi Nobel-díjat kapott.

A komputertomográfia a röntgen-átvilágítási technika továbbfejlesztésének tekinthető. A tomográfiás felvétel esetében vékony, síkszerü röntgensugárnyalábbal világítják át a vizsgált objektumot. Az objektum mögött elhelyezett detektor egy vonal mentén érzékeli, hogy a sugárnyalábból hol és mennyi nyelődött el. Az eljárás befejeztével a vizsgált test térbeli szerkezete feltérképezhető. ${ }^{42}$ A modern CT-berendezések egy körülfordulás alatt egyszerre több (akár 128) szeletet térképeznek fel, és egy vizsgálat a szükséges

41 http://www.jofri.net/

42 http://www.forensicmag.com/article/2009/08/necro-radiology-postmortem-ct-scans-are-rise 
számítások elvégzésével együtt néhány perc alatt elvégezhető, így alkotva meg a vizsgált objektum térbeli rekonstrukcióját. ${ }^{43}$

\section{MRI}

Az MRI (Magnetic Resonance Imaging) jelentése mágnesesmagrezonanciaképalkotás. A technikát elsősorban az orvosi diagnosztikában használják a test szerkezetének leképezéséhez. Emellett az agyi képalkotás területén is alkalmazzák. Előnye a komputertomográfiához képest, hogy jobb a kontrasztfelbontó képessége a lágy szövetek területén. Létezik a strukturális MRI-vizsgálat (sMRI) mellett úgynevezett funkcionális mágnesesrezonancia-vizsgálat (fMRI) is, amellyel a vizsgált szervek müködéséről kapható információ. Az MRI valójában inkább eszközök gyüjteményének tekinthetö, egy nagyon öszszetett képalkotó eljárás. ${ }^{44}$

\section{$M D C T$}

A hosszú vizsgálati idő, a számottevő sugárterhelés és a leletek gyakori értékelhetetlensége miatt szükség volt technológiai váltásra. Az orvosi berendezések folyamatos fejlődésével ma már negyedik generációs multidetektoros (többszeletes spirál) CT (MDCT) berendezések állnak rendelkezésre, amelyek előnye a magas szeletszám, a megfelelő tér- és időbeli felbontás, valamint a pácienst érő sugárterhelés mérséklődése. Ezekkel a modern berendezésekkel ma már akár egy-két másodperc alatt elvégezhető a vizsgálat. Megjegyzendő, hogy bár néhány perc alatt több ezer képet készíthetünk, ezek kiértékelése nyilván sokkal több időt vesz igénybe. A 2005-ben bemutatott két sugárforrású dual-source CT (DSCT) - amilyet a Pozitron-diagnosztika Központ is használ - ilyen készülék. A DSCT felépítése abban különleges, hogy a berendezésben két különálló 64 szeletes felvételező rendszer van egymáshoz képest 90 fokban elforgatva, elhelyezve, amelyekkel negyed fordulat alatt leképezhető a teljes látómező. ${ }^{45}$

\section{A bünügyi célú ujj-és tenyérnyomat-felvételi munkaállomás}

A bünügyi nyilvántartásba vétel során számos ujj- és tenyérnyomatok felvételét elősegítő eszköz alkalmazható.

\footnotetext{
43 http://www2.le.ac.uk/departments/emfpu/imaging/brief-history $44 \mathrm{http}: / /$ emedicine.medscape.com/article/1785023-overview 45 http://emedicine.medscape.com/article/1785023-overview\#a2
} 
A LiveScan berendezés szoftvere az ujj- és tenyérnyomatokat elektronikusan rögzíti és dolgozza fel. A rendszer tökéletesen illeszkedik a Cogent automatizált ujjlenyomat-azonosító rendszerhez (CAFIS). A munkaállomás a bünügyi célú ujj- és tenyérnyomat-rögzítés teljes folyamatát lefedi, alkalmas a nyomok rögzítésére, az adatbevitelre, a nyomatlap nyomtatására és a rögzített adatok továbbítására. Az ujj- és tenyérnyomatok rögzítéséhez a CS500P élőolvasó szkenner szükséges. A termék az FBI által hitelesített.

A nyomatrögzítés a személyes adatok bevitele után három fázisból áll:

- a tízujjas sík nyomatok levétele;

- a tízujjas átforgatott nyomatok levétele; valamint

- a tenyérnyomatok levétele.

A nyomatok levétele előtt meg kell győződni arról, hogy az alany keze és a LiveScan üveglapja tiszta és szennyeződésmentes. Ha az alany bőre túlságosan izzadt vagy túl meleg, a nyomat túl sötét lesz. Ebben az esetben az alany kezének megtisztítása szükséges. Ha az alany bőre túl száraz, vagy túl hideg, a nyomat túlságosan világos lesz, ez esetben nedvesítésre van szükség. Ha a sík ujjnyomok gyenge minőségủek, a rendszer folyamatosan hibaüzenetet jelenít meg, amikor az átforgatott ujjnyomok fázisában vagyunk, mert nincs összehasonlításra alkalmas, megfelelő nyomat. Ha a rendszer egy ujjnyomatot annak gyenge minősége miatt vagy a helytelen sorrend miatt elveti, figyelmeztet, hogy rögzítsük újra az adott ujjnyomatot.

A LiveScan egy átforgatottujjnyomat-rögzítő ablakot kínál fel minden egyes ujj számára. Ebben a szakaszban a rendszer nemcsak a képek minőségét ellenőrzi, de a helyes sorrend érdekében összeveti őket a már meglévő sík ujjnyomatok képeivel.

A tenyérnyomat levételénél külön figyelmet kell fordítani a tenyér felső részének erős nyomására (interdigitális terület), mert ez a rész a tenyérnyomat kiértékelésénél jelentős információkkal szolgál a szakértőknek. Ha sérülés vagy amputáció van valamelyik kézen, ez bejelölhető a rendszerben.

A nyomatvétel után a küldés gomb megnyomásával a szoftver az adatokat automatikusan továbbítja a központi nyilvántartásnak, amely minden tranzakcióra válaszüzenetet küld. ${ }^{46}$

46 LiveScan Bünügyi célú ujj- és tenyérnyomat felvételi munkaállomás felhasználói kézikönyv. ORFK, Budapest, 2011 


\section{Az Alphonse személyleirási rendszer}

A büncselekményt elkövető személyt némely esetben tanúk látják. A tanúk ideértve a sértettet is - kihallgatásakor nemcsak a cselekmény lefolyásáról szükséges kikérdezni, hanem az elkövető személyére vonatkozóan is, különösen akkor, ha nincs térfigyelő kamera, az elkövető elhagyta a helyszínt, illetve személyazonossága ismeretlen. Mára lehetőség nyílt az elkövetőről adott személyleírást számítógépes program segítségével feldolgozni és megjeleníteni, ami nagyban segíti a hatóságokat.

A rendszert Alphonse Bertillonról, az antropometria és az első személyleírási rendszer megalkotójáról nevezték el. A fényképfelvételek, az ujj- és tenyérnyomatok, valamint a DNS-profilok mellett a személyleírásnak is nagy jelentősége van az azonosításban. A rendőrségi programba integrált (Robotzsaru Neo) modul lehetővé teszi, hogy az elkövetőt észlelő személy minden olyan külső tulajdonságot megadjon, amely azonosíthatóvá teszi a terheltet. A program lehetőséget nyújt, hogy lépésről lépésre, tetőtől talpig felvigyék azokat az elkövetőt jellemző ismérveket a járástól kezdve a piercingig.

A személyleírási rendszer kidolgozásában részt vettek orvos szakértők, antropológusok, nyelvészek, tetoválómủvészek, fodrász és piercingszakértők is abból a célból, hogy a legátfogóbb fogalmakat és képi megjelenítési módokat integrálják a rendszerbe. Ennek köszönhetően a legapróbb részletekig leírható, hogy az elkövetőnek milyen volt például az orra, a szája, a járása, a tetoválása, a bőrszíne és még sok más jellemzője.

A rendszerbe vitt adatok segítséget nyújtanak abban, hogy a nyomozó hatóságok keresést hajtsanak végre benne, ezáltal összekapcsolhatóvá válhatnak helyszínek, elkövetők, büncselekmények. Például segítséget nyújthat abban az esetben, ha Budapesten elkövetnek egy rablást, majd a szemtanúk a tettes testfelépítéséről, vagy akár tetoválásáról részletes leírást adnak. Ebben az esetben a rendszerbe szükséges az adatokat bevinni, majd keresést végrehajtani, amelynek eredményeképp egy korábban nyilvántartásba vett személy kerülhet látótérbe. ${ }^{47}$

\section{IRODALOMJEGYZÉK}

Beck Attila: Az UAV-k polgári alkalmazásának kockázatai, és kezelésük lehetséges módszerei terrorelhárítási és személyvédelmi szempontból. (T)error\&elhárítás, 2015/2.

\footnotetext{
47 Az ORFK Bünügyi Értékelö-Elemző Osztály 8/E/2016/5876-os számú akkreditált képzési programja. Budapest, 2016
} 
Dutelle, Aric W.: An Introduction to Crime Scene Investigation. Second Editon. Jones \& Bartlett Learning, 2014

Fenyvesi Csaba: A kriminalisztika tendenciái. Dialóg Campus Kiadó, Budapest-Pécs, 2014

Genge, Ngaire: The Forensic Casebook. The Science of Crime Scene Investigation. Ballantine Books, New York, 2002

Havancsák Károly - Dankházi Zoltán: Pásztázó elektronmikroszkópia. ELTE anyagfizikai tanszék, Budapest, 2016

Lidstone, Ken - Bevan, Vaughan - Palmer, Clare: Bevan and Lidstone's The Investigation of Crime. A Guide to Police Powers. Second Editon, Butterworths, 1996

Lothridge, Kevin: Crime Scene Investigation: A Guide for Law Enforcement. National Forensic Science Technology Center, 2013

Lyman, Michael D.: Criminal Investigation. 8th Editon. Pearson, Columbia College of Missouri, 2016

Mama Sándor - Gárdonyi Gergely: A talajradar használatának gyakorlati tapasztatai a hazai bünügyi helyszínelésben. Belügyi Szemle, 2016/7-8.

Nagy Attila: Pilóta nélküli légi járművek - a technológia bemutatása, aktualitásai, jogi háttere. Szakmai Szemle, 2015/2.

Pásztor László: A 3D térszkenner müködése, tapasztalatok, lehetséges további felhasználási területek. Belügyi Szemle, 2016/7-8.

Petrétei Dávid: A drónok krimináltechnikai és rendészeti felhasználása. Magyar Bünüldözö, 2015/1-3.

Petrétei Dávid: Háromdimenziós képalkotás a kriminalisztikában. Belügyi Szemle, 2016/7-8.

Petrétei Dávid: Kriminalisztikai fényképészet - helyszínek fényképes dokumentálása. In: Szabó Gyula (szerk.): Munkabaleseti helyszínek dokumentálása. Óbudai Egyetem, Budapest, 2014, 11-12. o.

Szakács Hajnalka - Varga Csilla - Nagy Roland: Polimerek méréstechnikája. Pannon Egyetem, Budapest, 2012

Tóth Zsolt: A Hitachi S4700 pásztázó elektronmikroszkóp bemutatása és kezelési útmutatója. Szeged, 2006

Vránics Dávid - Üveges András: Pilóta nélküli légi járművek fejlődése. Felderitő Szemle, 2015/2. 